\title{
Communication
}

\section{Neoliberalism and the Environment: Are We Aware of Appropriate Action to Save the Planet and Do We Think We Are Doing Enough?}

\author{
Ellie-Anne Jones and Rick Stafford *(D)
}

check for updates

Citation: Jones, E.-A.; Stafford, R. Neoliberalism and the Environment: Are We Aware of Appropriate Action to Save the Planet and Do We Think We Are Doing Enough? Earth 2021, 2, 331-339. https://doi.org/10.3390/ earth2020019

Academic Editor: Charles Jones

Received: 10 May 2021

Accepted: 19 June 2021

Published: 21 June 2021

Publisher's Note: MDPI stays neutral with regard to jurisdictional claims in published maps and institutional affiliations.

Copyright: (c) 2021 by the authors. Licensee MDPI, Basel, Switzerland. This article is an open access article distributed under the terms and conditions of the Creative Commons Attribution (CC BY) license (https:/ / creativecommons.org/licenses/by/ $4.0 /)$.
Centre for Ecology, Environment and Sustainability, Department of Life and Environmental Sciences, Bournemouth University, Poole BH12 5BB, UK; s4907168@bournemouth.ac.uk

* Correspondence: rstafford@bournemouth.ac.uk; Tel.: +44-(0)-1202-966780

\begin{abstract}
We currently face several interlinked environmental crises, including climate change, habitat destruction and biodiversity loss. However, many governments seem unwilling to take strong and immediate action to address these threats, preferring to promote neoliberal approaches to allow consumers and the general public to make environmentally friendly choices. This is despite neoliberal approaches being much less likely to be successful than government leadership, taxation, subsidies, and legislation in addressing environmental issues. In this study, we examine public perception of environmental threats and solutions to these threats in a survey mainly completed in the UK. Climate change is seen as the biggest issue, likely due to recent activist campaigns and subsequent media attention on the issue. Neoliberal attitudes, such as green consumer choices to environmental concerns, do still dominate in a series of possible presented solutions, and they score more highly than lifestyle changes, such as changing diet. However, when questioned specifically about plastic pollution, government intervention to ban all unnecessary plastic scored very strongly, indicating a shift from a consumer-driven response. Furthermore, most participants think they are at best only partly "doing their bit" to protect the environment. The results demonstrate that the public is aware that not enough is happening to protect the environment and provide evidence that there is willingness for stronger government intervention to address environmental issues; however, there is potential resistance to major lifestyle changes.
\end{abstract}

Keywords: neoliberalism; environmental awareness; climate change; plastic pollution; environmental activism

\section{Introduction}

The neoliberalist theory, which began to dominate the Western economy in the 1980s, still provides the central economic and political ideology that shapes our world today [1]. Neoliberalism proposes that free markets ultimately lead to individual liberation [2], as well as efficiency and economic benefits in the absence of state intervention [3,4].

While the 1980s saw the growth of this ideology which still dominates economic and political thinking, the 1990s and subsequent decades have provided growing evidence for multiple global environmental problems. The planetary boundaries framework described by Steffen et al. [5] shows that, environmentally, we are operating well beyond safe global limits, especially with regard to pollution, such as nitrates and phosphates; climate change; habitat loss; and biosphere integrity. Climate and biosphere integrity are also described as core planetary boundaries, which can reach a tipping point, pushing the earth system into a new state, such as a significantly warmer "hot house Earth" if exceeded with sufficient magnitude and for sufficient time [6].

There is a clear, and well documented, mismatch between economic systems which focus on economic growth, and the environmental crisis [7-9], yet the neoliberal economic framework also hinders government interventions in addressing environmental issues, 
by preferring market-based solutions to interventions such as taxation, subsidies and legislation [10]. Strong environmental governance requires state involvement [11,12], and relying solely on market forces can result in marginal, if any environmental benefits. Reliance on market forces can lead to "eco-consumerism" which may ease the guilt of the consumer but have little tangible environmental effect $[10,13]$.

This lack of government intervention, alongside the escalating magnitude and urgency of environmental issues, has sparked people such as Greta Thunberg to apply pressure to national and international bodies, leading to the climate emergency being declared [14]. The widespread support for these campaigns such as Thunberg's school strikes and Extinction Rebellion, which demand "system change" suggests significant proportions of the public understand the urgency of the environmental problems we face and support greater stateled intervention in addressing these issues. Nevertheless, there is still a strong underlying narrative of consumer choice in environmental issues, even from commentators which normally oppose neoliberal frameworks. For example, the "stop eating seafood" message from the recent documentary Seaspiricy has had considerable publicity and support from environmental commentators [15], despite widespread condemnation from the marine science community [16].

Here we examine public perception of environmental issues and solutions, from a predominantly UK-based survey conducted in 2019. We specifically examine whether the public are aware of the biggest environmental issues, rather than less important (although still highly significant) environmental problems such as plastic pollution, and whether they are more likely to consider consumer-based (neoliberal-market-based) or activist-based, or lifestyle change solutions to address these problems as more effective. Finally, we examine if the public think they have done enough themselves to address environmental issues, specifically with respect to actions taken to reduce single use plastic. These results can help inform public supportive environmental policies in the future.

\section{Materials and Methods}

An online questionnaire was prepared to determine individual attitudes towards the environment, in particular their views on the most pressing environmental issues, and the best approaches on how to solve these. The questionnaire was released in the summer of 2019 (July, August and September), around a year after the global school strike movement and beginning of Extinction Rebellion protests, and before the Covid-19 pandemic. The study was granted ethical approval under Bournemouth University guidelines prior to releasing the survey to participants. The duration of the study was determined by the number of participants, and data collection stopped shortly after 100 participants had completed the survey.

The online questionnaire allowed the survey to be distributed to a wider demographic with a global reach [17]; however, a majority of results were from UK participants (see results). The questionnaire was promoted though social media channels (specifically Facebook and Twitter) and due to the following of the authors, who initially promoted this, may have a bias towards participants with higher than average interest in environmental issues. By conducting the questionnaire online, responses are more honest due to the anonymity of the survey $[18,19]$, making it easier for people to disclose views which may be sensitive in nature $[20,21]$ or seen as controversial.

The questions analyzed are shown in Table 1. Open answers (e.g., other) were not allowed for these questions, as this forced participants to choose from the list provided. This was especially important for the "most important actions to address" questions (Table 1). For the most important actions to address environmental issues, participants were presented choices of consumer-based actions, lifestyle changes and activist or educational actions in which they would be able to easily partake at an individual level if they chose to. Potential optimal solutions (e.g., changing the economic system) were specifically not presented as options, so choice was restricted to identify whether consumer-based, or equivalent non-consumer-based actions would be considered most appropriate. For the 
"most appropriate action to address plastic pollution" question (Table 1) we compared technological solutions, consumer-based solutions and government legislation. The choice of options again restricted responses to these categories, rather than larger-scale, less directed solutions such as "system change".

Table 1. Questions from the survey that were analyzed in this study and the categories or answers that the participants could select.

\begin{tabular}{|c|c|}
\hline Question & Responses \\
\hline 1. Please select your age range & $18-24,25-30,31-40,41-50,51-60,60+$ \\
\hline 2. Please select your gender & Female, male, other \\
\hline 3. What is your highest education level? & $\begin{array}{l}\text { School (GCSE or equivalent), post } 16 \text { education (including college or sixth } \\
\text { form), undergraduate, postgraduate }\end{array}$ \\
\hline $\begin{array}{l}\text { 4. What do you think is the most important } \\
\text { environmental issue at the moment? (only one } \\
\text { selection possible) }\end{array}$ & $\begin{array}{l}\text { Climate change, deforestation, biodiversity loss (mass extinction), } \\
\text { overpopulation, pollution (air, water, etc.), plastics in the ocean }\end{array}$ \\
\hline $\begin{array}{l}\text { 5. Please rate the following activities in terms of their } \\
\text { importance to protecting the environment }\end{array}$ & $\begin{array}{l}\text { Purchase power, living a zero-waste lifestyle, protests and strikes, social } \\
\text { media and blog posts, vegetarian diet, vegan diet, buying products made } \\
\text { with organic materials (1 (low) to } 7 \text { (high) response) }\end{array}$ \\
\hline $\begin{array}{l}\text { 6. Please rate the following activities in terms of their } \\
\text { importance to reducing plastic pollution }\end{array}$ & $\begin{array}{l}\text { Plastic removal technology (e.g., Ocean Clean-Up), improved recycling } \\
\text { technology, reusable carrier bags, access to plastic free aisles in shops, } \\
\text { greater access to recycling centers, banning single use plastics. (1 (low) to } \\
7 \text { (high) response) }\end{array}$ \\
\hline $\begin{array}{l}\text { 7. Do you think you have "done their bit" to protect } \\
\text { the planet? }\end{array}$ & No, partly, maybe, yes \\
\hline
\end{tabular}

The opinion-based questions in the survey were presented alongside a Likert scale response from 1 to 7 , as such options give greater resolution of answers to which participants are unsure [22]. A majority of results are summarized graphically; however, to determine if participants responded differently to possible solutions depending on the environmental issues they thought to be most important, the interaction term of a two-way ANOVA was examined and conducted by using the glm function in R [23] with Poisson distribution to approximate for the distribution from ordinal dependent variables [24]. The score given to the importance of different pro-environmental activities (Q5 in Table 1) was the dependent variable, with the category of most important issue (e.g., purchase power, zero-waste lifestyle and Q5 in Table 1) and the selection of the most important environmental issue (Q4 in Table 1) as fixed independent factors in the analysis.

\section{Results}

\subsection{Overview of Survey Participants}

The questionnaire returned 118 responses, but before these could be analyzed, the incomplete responses were removed, leaving 100 responses (because of this, numbers of participants giving certain answers are given in the results, which also equate to percentage of participants). The demographic data of the participants are given in Table 2. As indicated in the methods, the promotion of the questionnaire initially through social media contacts of the authors is likely to lead to some bias in selecting for pro-environmental participants. However, the questionnaire was open to all and beyond the demographics presented; thus, it is not possible to further determine the participants of the survey. However, it is most likely to be representative of a subpopulation of the UK population which is typically younger and more educated than average and mainly have some interest in environmental issues. It should be noted, however, that the relatively small sample size is a limitation of this study. 
Table 2. Demographic characteristics of survey participants. $\mathrm{N}=100$.

\begin{tabular}{ll}
\hline Demographic Characteristic & Responses \\
\hline \multirow{3}{*}{ Gender } & Female-57 \\
& Male-41 \\
& Other-2 \\
\hline \multirow{2}{*}{ Education (highest qualification being pursed } & Completed School (18+)-26 \\
or completed) & Undergraduate degree-49 \\
& Masters or higher level degree-25 \\
\hline & $18-25-38$ \\
Education & $25-30-19$ \\
$*$ several older age categories combined & $25-30-15$ \\
& $30-40-17$ \\
& $40-50-17$ \\
Location & $50+-11 *$ \\
\hline
\end{tabular}

\subsection{Identified Environmental Threats and Solutions}

The environmental threat identified as the greatest in the survey was that of climate change (Figure 1), with other threats receiving only around 25 to $40 \%$ of the number of responses. Solutions to environmental problems (from the choices presented) showed preference for consumer-based approaches, with purchase power showing the highest scoring, and "activist" type approaches scoring lower (Figure 2). Changes which would significantly alter lifestyles (e.g., diet) scored lowest of all (Figure 2).

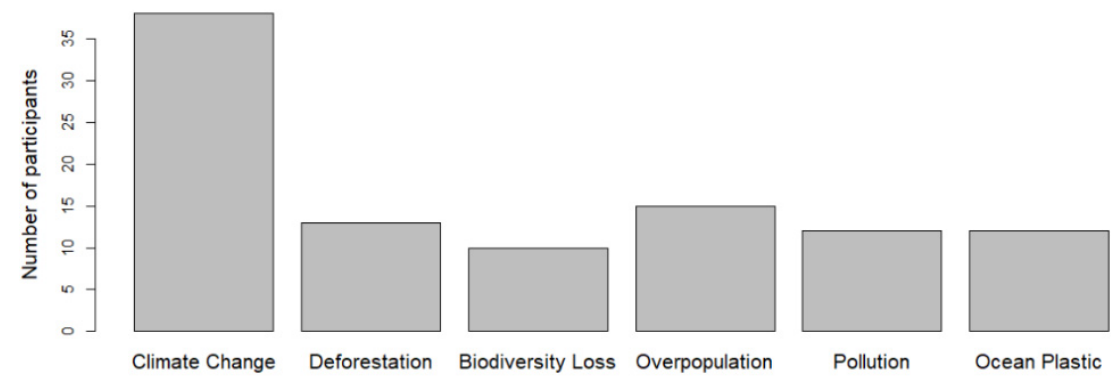

Figure 1. Number of respondents selecting what they perceive as the biggest environmental threat.

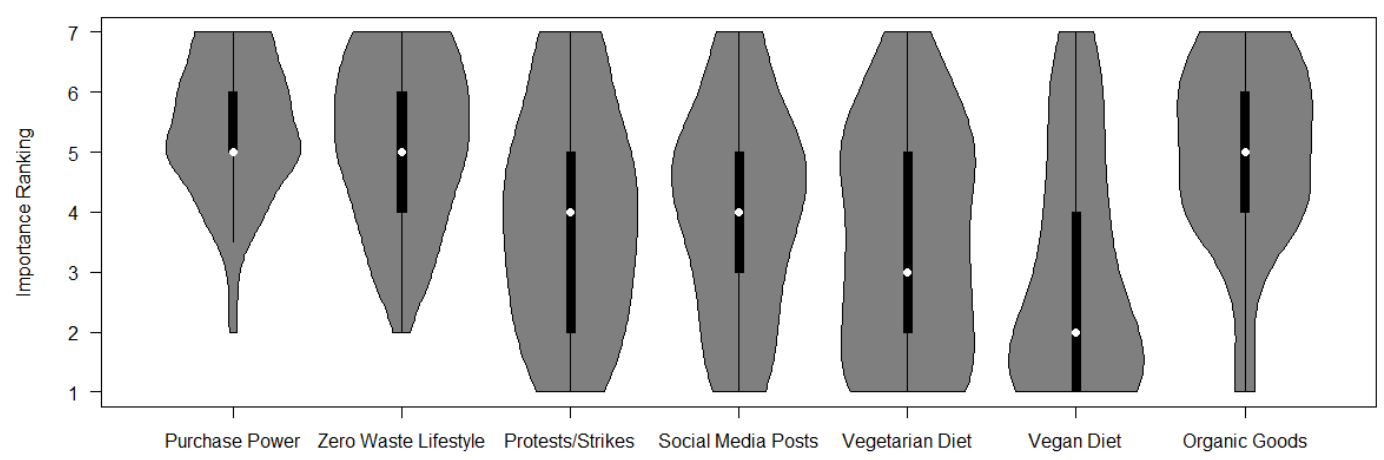

Figure 2. Violin plot of most important actions to take to address environmental issues. White dot indicates the median score given, with black bar indicating the IQR.

The majority of solutions to address plastic waste scored well, with "reusable carrier bags" scoring lowest, and "banning single use plastics" receiving the highest score (Figure 3). 


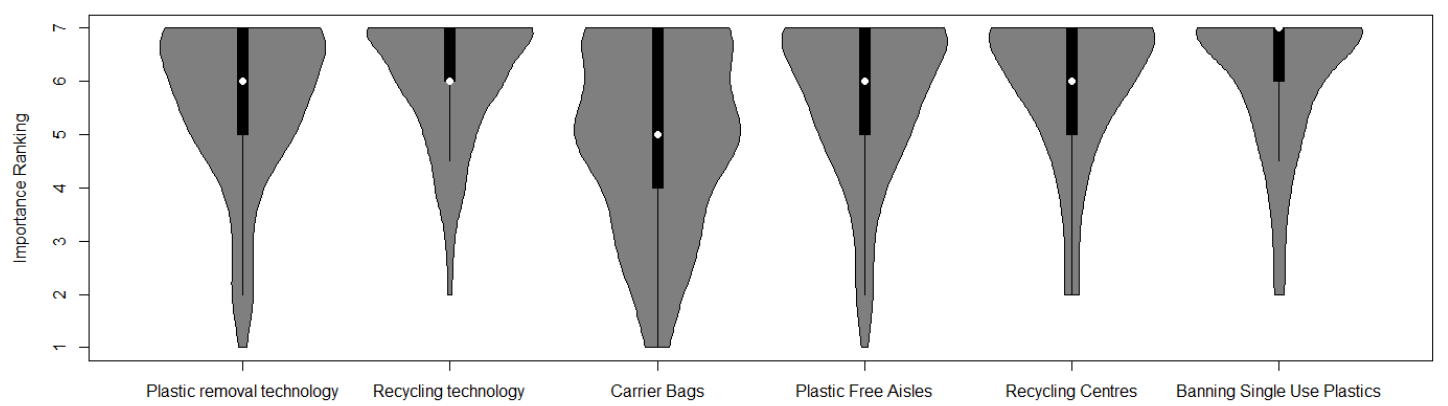

Figure 3. Violin plot of most important actions to take to address plastic pollution. White dot indicates the median score given, with black bar indicating the IQR.

There was no significant interaction term in the generalized linear model ANOVA of overall score given to an action against the action type and respondent identification of the most important environmental threat (deviance $=27.8$, d.f. $=30,654, p=0.579$ ). This indicates that there are not significant differences between the importance of actions, regardless of what people see as the most important threat. However, those identifying extinction and biodiversity loss as the major threat had a higher median score across all actions ( 6 as compared to 5 for all other categories; deviance $=14.5$, d.f. $=5,690, p=0.0126$ ).

The majority of participants also thought they had, at best, partly "done their bit" to reduce environmental issues (Figure 4), with fewer people thinking they had done their bit if they selected plastic pollution as the biggest issue than other threats (Figure 4).

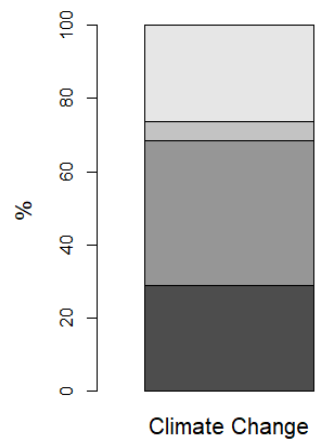

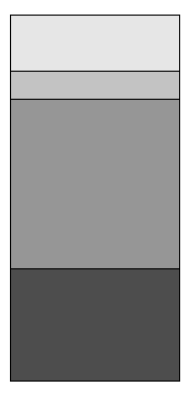

Deforestation

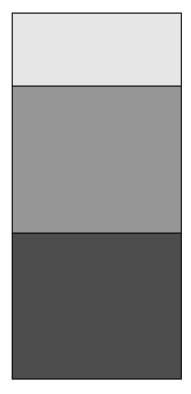

Biodiversity Loss

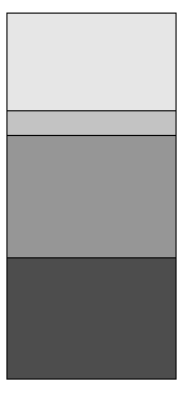

Overpopulation

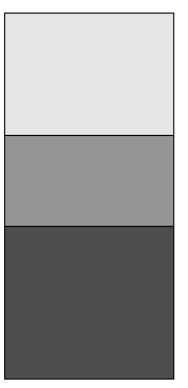

Pollution

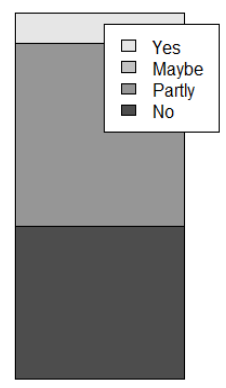

Ocean Plastic

Figure 4. Proportion of respondents to the question "Do you think you have 'done their bit' to protect the planet?" categorized by the respondent's classification of biggest environmental threat.

\section{Discussion}

With ongoing climate strikes and action from environmental groups such as extinction rebellion at the time of the survey, public opinion of UK citizens surveyed here clearly demonstrated climate change was the major perceived environmental threat. When presented with consumer-based, lifestyle-based or activist-based "solutions" to environmental problems, consumer-based approaches were still thought to be the most effective; although, when state intervention (legislation) for plastic pollution was presented as a solution, it was a more popular choice than technological or consumer-based options. Most participants also felt that they had not "done their bit" for the environment with actions they had taken.

\subsection{Environmental Threats}

Climate change was perceived as the major environmental threat by almost half the survey participants. While this is undoubtedly a major threat, it is only one of the exceeded planetary boundaries, with biodiversity loss and climate change being "core" planetary boundaries [5]. This does suggest campaign groups, media reporting and public engagement may have had a biased focused on climate in 2019 [25]. However, perhaps the best publicized example of risk of biodiversity loss in 2019, the bleaching of the Great Barrier 
Reef and other coral reefs, also has climate change as the main driver [26], illustrating the interlinked nature of these threats.

While there are few datasets surveying public opinion on environmental issues from the early 2010s, these current findings from our 2019 survey do contrast with some other earlier work. For example, Marshall et al. [27] show from a survey conducted in 2013/2014 on beaches near the Great Barrier Reef, that plastic was by far the biggest concern of local residents. The dominant environmental media narrative in western society from the early to mid-2010s was also that of plastic pollution [10]. Hence, it is likely that the work of activist groups, such as Extinction Rebellion, have raised the importance of the issue of climate change in the public mindset in recent years.

\subsection{Effective Actions}

Despite the possible important role of activist groups highlighted above, respondents ranked consumer-based actions (from the list provided) as the most effective actions to address environmental issues, demonstrating that the dominant neoliberal narrative highlighted in Stafford and Jones [10] is still apparent. While still an individual and consumer-based action, switching to diets dominated by plant-based products have been shown to be one of the most effective actions to reduce personal carbon footprints [28,29], yet these scored lowest of all in the survey. This may illustrate a lack of willingness to make large-scale changes to lifestyle, despite participating in smaller-scale responses such as buying more environmentally friendly packaged items. However, there was a high ranking given to zero-waste lifestyles, which if performed properly, would require significant changes to lifestyle [30]. It is unclear if people are unwilling, or lack knowledge about the large environmental effect of diet; however, we can conclude that the effective action ranking given to all actions did not differ depending on which threat participants selected as most important. This is somewhat surprising, as threats such as habitat and biodiversity loss would be more directly associated with land use change, often down to food-production methods [31,32].

When presented with actions to reduce plastic waste, however, legislative government action on all single-use plastics was ranked highest; however, consumer- and technologicalbased solutions still scored well. Reusable carrier bags scored lowest, perhaps because this action has already been implemented, and plastic waste is still prevalent. The strong support for banning single use plastics, however, does pave the way for public support for stronger government action on the issue. For example, the UK government has committed to banning "avoidable" plastic waste by 2043 [33]. These results would indicate that there is there is public support to bring this deadline forward considerably.

Theories such as the Environmental Kuznets Curve do suggest that, over time, and over increasing levels of economic growth, environmental threats begin to decline [34], ultimately supporting the economic growth and lack of legislation approach favored by neoliberalism. However, such approaches have been developed based on localized pollution metrics, rather than global issues, such as climate change [34]. While better waste management systems have reduced the effects of plastic pollution in the Global North, compared to the Global South [35], per capita carbon footprints are much higher in the Global North, despite much higher levels of GDP, and evidence suggest "decoupling" carbon emissions from GDP is at best, partial [36]. As such, much academic research does point towards the need for effective legislation and economic reform to effectively tackle major environmental issues (e.g., see References [7-10]).

\subsection{Have Participants "Done Their Bit"?}

The vast majority of participants did not feel that they have "done their bit" for the environment, and a greater proportion of participants selecting ocean plastic thought that they had not done their bit. These results indicate the "complacency" angle of plastic waste hypothesized in Stafford and Jones $[10,37]$ may not be as greater concern as hypothe- 
sized. However, the results on effective actions, discussed above, do illustrate the lack of "spillover" from consumerist to other types of action [38].

Ultimately, while there is knowledge that more needs to be done, for actions such as climate change, the likely cause of action from the public is still that of consumer pressure [39]. Trying to persuade a nation to alter their behavior, without explicit environmental incentives (i.e., high carbon or pollutant taxes, or subsidies on lower carbon food products), is a complex and challenging task. Legislative forcing of companies to alter their production methods, or the products that they offer, may be quicker and more effective, and ultimately easier, although likely to be politically challenging [40]. However, unless collaborative efforts are directed to global mitigation of all environmental issues, goals will become unachievable [41].

\section{Conclusions}

This study shows that there appears to have been a shift in emphasis in public perception from plastic to climate as the main environmental threat, albeit from the current survey from a subpopulation of participants with interest in environmental problems. This is likely to be a result of international campaigns, illustrating the importance of environmental activism. Nevertheless, the survey participants did not rank activism highly, and they focused on consumer-driven responses to address most environmental issues. However, support for government legislation, in relation to plastic, was apparent, and participants did not feel that simply reducing plastic use meant they had done enough to benefit the environment. Collectively, these results support two actions:

1. Since activist campaigns appear to work in promoting awareness, but currently less well in promoting effective actions, activists, charities, NGOs and political parties interested in promoting environmental solutions should now campaign strongly for effective actions, such as legislative and economic processes, as per comprehensive Green New Deal or Green Recovery plans, which have been predicted to be highly effective against all environmental threats [9].

2. To alert government and policymakers that there is public support for more urgent legislative environmental action, such as a more immediate ban on unnecessary plastic.

Author Contributions: Conceptualization, E.-A.J.; methodology, E.-A.J.; formal analysis, E.-A.J. and R.S.; investigation, E.-A.J. and R.S.; data curation, E.-A.J. and R.S.; writing—original draft preparation, E.-A.J. and R.S.; writing - review and editing, E.-A.J. and R.S.; visualization, R.S.; supervision, R.S. Both authors have read and agreed to the published version of the manuscript.

Funding: This research received no external funding.

Institutional Review Board Statement: The study was conducted according to the guidelines of the Declaration of Helsinki, and approved by the Ethics Review Process of Bournemouth University (protocol code 27665 14/7/2019).

Informed Consent Statement: Informed consent was obtained from all subjects involved in the study.

Data Availability Statement: Data and analysis code were deposited on the Bournemouth University Online Research Data Depository available at https:/ / doi.org/10.18746/bmth.data.00000158. (accessed on 10 April 2021).

Acknowledgments: We would like to thank the three reviewers of the manuscript for their valuable comments that helped improve this work.

Conflicts of Interest: The authors declare no conflict of interest.

\section{References}

1. Saad-Filho, A.; Johnston, D. Neoliberalism: A Critical Reader, 1st ed.; Pluto Press: London, UK, 2005.

2. Hayek, F. Law, Legislation and Liberty: A New Statement of the Liberal Principles of Justice and Political Economy. Rule and Order, 1; Routledge: London, UK, 1973.

3. Harvey, D. Brief History of Neoliberalism; Oxford University Press: Oxford, UK, 2005.

4. Thorsen, D.; Lie, A. What is Neoliberalism? Department of Political Science University of Oslo: Oslo, Norway, 2019. 
5. Steffen, W.; Richardson, K.; Rockstrom, J.; Cornell, S.; Fetzer, I.; Bennett, E.; Biggs, R.; Carpenter, S.; de Vries, W.; de Wit, C.; et al. Planetary boundaries: Guiding human development on a changing planet. Science 2015, 347, 1259855. [CrossRef]

6. $\quad$ Steffen, W.; Rockström, J.; Richardson, K.; Lenton, T.M.; Folke, C.; Liverman, D.; Summerhayes, C.P.; Barnosky, A.D.; Cornell, S.E.; Crucifix, M.; et al. Trajectories of the Earth System in the Anthropocene. Proc. Natl. Acad. Sci. USA 2018, 115, 8252-8259. [CrossRef] [PubMed]

7. Raworth, K. Doughnut Economics: Seven Ways to Think Like a 21st Century Economist; Random House: London, UK, 2017.

8. Hickel, J. Less is More: How Degrowth will Save the World; William Heinemann: London, UK, 2020.

9. Stafford, R.; Croker, A.R.; Rivers, E.M.; Cantarello, E.; Costelloe, B.; Ginige, T.; Sokolnicki, J.; Kang, K.; Jones, P.J.S.; McKinley, E.; et al. Evaluating optimal solutions to environmental breakdown. Environ. Sci. Policy 2020, 112, 340-347. [CrossRef]

10. Stafford, R.; Jones, P. Viewpoint-Ocean plastic pollution: A convenient but distracting truth? Mar. Policy 2019, 103, 187-191. [CrossRef]

11. Jones, P.J.; Long, S.D. Analysis and discussion of 28 recent marine protected area governance (MPAG) case studies: Challenges of decentralisation in the shadow of hierarchy. Mar. Policy 2020, 127, 104362, in press. [CrossRef]

12. Jones, P.J.S.; Stafford, R.; Maslin, M. What Covid-19 can teach us about governance. The Ecologist. Available online: https: // theecologist.org/2020/apr/08/what-covid-19-can-teach-us-about-governance (accessed on 10 April 2021).

13. Dauvergne, P.; Lister, J. The Prospects and Limits of Eco- Consumerism: Shopping Our Way to Less Deforestation? Organ. Environ. 2010, 23, 132-154. [CrossRef]

14. Soldati, C. The UK Becomes the First Country in the World to Declare a Climate Emergence. LifeGate. 2019. Available online: https://www.lifegate.com/people/news/uk-climate-emergency (accessed on 10 April 2021).

15. Monbiot, G. Seaspiracy Shows Why We Must Treat Fish not as Seafood, but as Wildlife. The Guardian. 2021. Available online: https://www.theguardian.com/commentisfree/2021/apr/07/seaspiracy-earth-oceans-destruction-industrial-fishing (accessed on 10 April 2021).

16. Pauly, D. What Netflix's Seaspiracy Gets Wrong about Fishing, Explained by a Marine Biologist. Vox. 2021. Available online: https: / / www.vox.com/2021/4/13/22380637/seaspiracy-netflix-fact-check-fishing-ocean-plastic-veganism-vegetarianism (accessed on 10 April 2021).

17. Evans, J.; Mathur, A. The value of online surveys. Internet Res. 2005, 15, 195-219. [CrossRef]

18. Denscombe, M. The Good Research Guide for Small-Scale Research Projects, 5th ed.; Open University Press: Maidenhead, UK, 2014.

19. Newing, H. Conducting Research in Conservation: Social Science Methods and Practice [Online]; Routledge: London, UK, 2011.

20. Fricker, R.D.; Schonlau, M. Advantages and Disadvantages of Internet Research Surveys: Evidence from the Literature. Field Methods 2002, 14, 347-367. [CrossRef]

21. Whelan, T. Anonymity and confidentiality: Do survey respondents know the difference? In Proceedings of the 30th Annual Meeting of the Society of Southeastern Social Psychologists, Durham, NC, USA, 31 October 2007.

22. Kragh, G. A Holistic Approach to Environmental Volunteering: Connections between Motivation, Well-Being and Conservation Achievement. Ph.D. Thesis, Bournemouth University, Bournemouth, UK, 2017.

23. R Core Team (2020). R: A language and environment for statistical computing. Vienna: R Foundation for Statistical Computing. Available online: https:/ / www.R-project.org/ (accessed on 10 April 2021).

24. Faraway, J.J. Extending the Linear Model with R. Generalized Linear, Mixed Effects and Nonparametric Regression Models, 2nd ed.; Routledge: London, UK, 2016.

25. Ginanjar, W.R.; Mubarrok, A.Z. Civil Society and Global Governance: The Indirect Participation of Extinction Rebellion in Global Governance on Climate Change. J. Contemp. Gov. Public Policy 2020, 1, 41-52. [CrossRef]

26. Hughes, T.P.; Anderson, K.D.; Connolly, S.R.; Heron, S.F.; Kerry, J.T.; Lough, J.M.; Baird, A.H.; Baum, J.K.; Berumen, M.L.; Bridge, T.C.; et al. Spatial and temporal patterns of mass bleaching of corals in the Anthropocene. Science 2018, 359, 80-83. [CrossRef]

27. Marshall, N.A.; Dunstan, P.; Pert, P.; Thiault, L. How people value different ecosystems within the Great Barrier Reef. J. Environ. Manag. 2019, 43, 39-44. [CrossRef]

28. Wynes, S.; Nicholas, K.A. The climate mitigation gap: Education and government recommendations miss the most effective individual actions. Environ. Res. Lett. 2017, 12, 074024. [CrossRef]

29. Poore, J.; Nemecek, T. Reducing food's environmental impacts through producers and consumers. Science 2018, 360, 987-992. [CrossRef]

30. Zaman, A.; Lehmann, S. Urban growth and waste management optimization towards 'zero waste city'. City Cult. Soc. 2011, 2, 177-187. [CrossRef]

31. Alexander, P.; Rounsevell, M.D.; Dislich, C.; Dodson, J.R.; Engström, K.; Moran, D. Drivers for global agricultural land use change: The nexus of diet, population, yield and bioenergy. Glob. Environ. Chang. 2015, 35, 138-147. [CrossRef]

32. Mora, O.; Le Mouël, C.; de Lattre-Gasquet, M.; Donnars, C.; Dumas, P.; Réchauchère, O.; Brunelle, T.; Manceron, S.; MarajoPetitzon, E.; Moreau, C.; et al. Exploring the future of land use and food security: A new set of global scenarios. PLoS ONE 2020, 15, e0235597. [CrossRef] [PubMed]

33. DEFRA, A Green Future: Our 25 Year Plan to Improve the Environment. London: Department for Environment, Fisheries and Rural Affairs. Available online: https:/ /www.gov.uk/government/publications/25-year-environment-plan. (accessed on 8 April 2021). 
34. Dasgupta, S.; Laplante, B.; Wang, H.; Wheeler, D. Confronting the environmental Kuznets curve. J. Econ. Perspect. 2002, 16, 147-168. [CrossRef]

35. Knoblauch, D.; Mederake, L.; Stein, U. Developing countries in the lead-what drives the diffusion of plastic bag policies? Sustainability 2018, 10, 1994. [CrossRef]

36. Parrique, T.; Barth, J.; Briens, F.; Kerschner, C.; Kraus-Polk, A.; Kuokkanen, A.; Spangenberg, J.H. Decoupling Debunked: Evidence and Arguments Against Green Growth as a Sole Strategy for Sustainability. European. Environmental Bureau, Brussels. 2019. Available online: Eeb.org/library/decoupling-debunked (accessed on 4 April 2021).

37. Stafford, R.; Jones, P.J.S. We should not separate out environmental issues, but the current approach to plastic pollution can be a distraction from meaningful action. A response to Avery-Gomm et al. Mar. Policy 2019, 107, 103585. [CrossRef]

38. Maki, A.; Carrico, A.R.; Raimi, K.T.; Truelove, H.B.; Araujo, B.; Yeung, K.L. Meta-analysis of pro-environmental behaviour spillover. Nat. Sustain. 2019, 2, 307-315. [CrossRef]

39. Cooper, T. Slower Consumption Reflections on Product Life Spans and the "Throwaway Society". J. Ind. Ecol. 2008, 9, 51-67. [CrossRef]

40. Nickerson, R.; Moray, N. Emerging Needs and Opportunities for Human Factors Research; The National Academies Press: Cambridge, MA, USA, 1995.

41. Peters, G.; Andrew, R.; Boden, T.; Canadell, J.; Ciais, P.; Le Quéré, C.; Marland, G.; Raupach, M.; Wilson, C. The challenge to keep global warming below $2{ }^{\circ} \mathrm{C}$. Nat. Clim. Chang. 2012, 3, 4-6. [CrossRef] 